\title{
MANAGEMENT OF ENDOCRINE DISEASE Subclinical hypothyroidism in children
}

\author{
Mariacarolina Salerno', Nicola Improda' ${ }^{1}$ and Donatella Capalbo ${ }^{2}$
}

'Department of Translational Medical Sciences, Paediatric Endocrinology Unit, University of Naples 'Federico II', Naples, Italy and 'Department of Mother and Child, Paediatric Endocrinology Unit, University Hospital 'Federico II', Naples, Italy

Correspondence should be addressed to M Salerno

Email

salerno@unina.it

\section{Abstract}

Subclinical hypothyroidism (SH) is biochemically defined as serum TSH levels above the upper limit of the reference range in the presence of normal free T4 (FT4) concentrations. While there is a general agreement to treat subjects with serum TSH levels above $10 \mathrm{mU} / \mathrm{L}$, the management of mild form (TSH concentrations between 4.5 and $10 \mathrm{mU} / \mathrm{L}$ ) is still a matter of debate. In children, mild SH is often a benign and remitting condition and the risk of progression to overt thyroid dysfunction depends on the underlying condition, being higher in the autoimmune forms. The major concern is to establish whether SH in children should always be considered an expression of mild thyroid dysfunction and may deserve treatment. Current data indicate that children with mild SH have normal linear growth, bone health and intellectual outcome. However, slight metabolic abnormalities and subtle deficits in specific cognitive domains have been reported in children with modest elevation of TSH concentration. Although these findings are not sufficient to recommend levothyroxine treatment for all children with mild SH, they indicate the need for regular monitoring to ensure early identification of children who may benefit from treatment. In the meanwhile, the decision to initiate therapy in children with mild SH should be based on individual factors.

\section{Introduction}

Subclinical hypothyroidism (SH), also known as isolated hyperthyrotropinemia or mild hypothyroidism, is a biochemical condition characterized by serum TSH concentrations above the upper limit of the reference range, but normal concentrations of free T4 (FT4) (1).

The upper limit of the normal range for TSH lays between 4.0-5 mU/L, but considerable differences exist in childhood across and within age ranges and laboratory assays (2). Therefore, it is advisable to diagnose SH after at least two independent measurements of TSH concentrations.

SH has been recently categorized as grade 1 , or mild, when TSH level is between the upper limit of the reference range and $9.9 \mathrm{mU} / \mathrm{L}$, and grade 2 , or severe, when TSH is $10 \mathrm{mU} / \mathrm{L}$ or higher (3).

\section{Invited Author's profile}

Mariacarolina Salerno is Associated Professor of Pediatrics at the University of Naples 'Federico II'. She is the Director of the Pediatric Endocrinology Unit and the Director of the Pediatric Nursing School of the University of Naples 'Federico II'. She is the President-elect of the Italian Society for Pediatric Endocrinology and Diabetology (ISPED). Her main research interest is on congenital and subclinical hypothyroidism, growth hormone deficiency, and cardio-metabolic alterations in pediatric endocrine diseases.

Published by Bioscientifica Ltd. 
In adults $\mathrm{SH}$ is a common finding with a prevalence up to $10 \%$ of the population (3). The vast majority of studies do not provide sufficient evidences to routinely recommend levothyroxine (L-T4) replacement in all adults with $\mathrm{SH}(4,5)$. International guidelines from American Thyroid Association and European Thyroid Association (6, 7) recommend treatment at TSH levels $>10 \mathrm{mU} / \mathrm{L}$, while for patients with a lower TSH threshold treatment decision should be based on symptoms and individual factors $(3,8)$.

Data regarding the prevalence of mild $\mathrm{SH}$ in children and adolescents are scanty. The results of the National Health and Nutrition Examination Survey (NHANES III), involving 1327 adolescents aged 13-16 years, revealed a prevalence of $\mathrm{SH}$ of $1.7 \%$ (9). Another study evaluating thyroid function tests performed during routine assessment in 121.052 children aged $0.5-16.0$ years showed a prevalence of mild SH of $2.9 \%$ (10).

In children, $\mathrm{SH}$ is often a benign and remitting condition and the long-term clinical consequences of increased TSH are still debated (11). Therefore, in children the need for L-T4 supplementation remains controversial, particularly in mild SH $(12,13,14)$.

In this review we summarize current knowledge on mild and persistent $\mathrm{SH}$ in children and provide suggestions for the management of this condition in childhood.

\section{Methods}

We searched the PubMed database from the National Library of Medicine by using the following keywords: 'Hashimoto thyroiditis', 'genetic syndromes', 'obesity', 'iodine deficiency', 'linear growth', 'cardiac morphology', 'cardiac function', 'neurocognitive outcome', 'bone health', 'cardio-metabolic risk', 'lipids', 'blood pressure', 'glucose metabolism', in combination with 'mild hypothyroidism' or 'mild thyroid dysfunction' or 'subclinical hypothyroidism' or 'hyperthyrotropinemia'. The limits were set to only English-language articles and those involving human subjects. We included all case-control studies, case series and meta-analysis that were published in English from 1990 to date. This search allowed us to identify several publications that were selected on the basis of research methodology and scientific relevance.

\section{Evolution of SH according to the etiology}

SH in children is often a benign and remitting condition and the risk of progression to overt thyroid dysfunction depends on the underlying condition. The main causes of SH in children are reported in Table 1.

\section{Hashimoto thyroiditis}

As for adults, the most frequent cause of $\mathrm{SH}$ in children is chronic Hashimoto thyroiditis (HT).

Data regarding the evolution of $\mathrm{SH}$ in children with HT are rather heterogeneous, depending on the variability in the number of patients enrolled, the years of follow-up and the severity of SH (3).

Recent studies on large cohorts of children and adolescents with HT indicate that up to $53 \%$ of children with mild elevation in serum TSH show progressive deterioration of thyroid function to overt hypothyroidism over a period of $1-5$ years $(15,16$, $17,18,19)$; in contrast, the rate of progression is only $10-15 \%$ in euthyroid subjects $(15,16,18,20)$. However, approximately $30-45 \%$ of children with mild HT-related SH normalize thyroid function tests during follow-up $(15,16,18,19,20,21)$.

Several factors have been associated with an increased risk of evolution into overt hypothyroidism, including age at presentation (22), the presence of goiter (21), higher TSH and thyroperoxidase autoantibodies (TPO $\mathrm{Ab}$ ) levels at diagnosis (16) and/or progressive increase in both TPO Ab and TSH concentrations over time (16, 21) Finally, the presence of other autoimmune conditions (i.e. celiac disease) or genetic syndromes (i.e. Down and Turner), in children with HT-related SH, is associated with an increased risk of developing overt thyroid dysfunction $(16,23,24)$.

\section{Genetic syndromes}

As shown in Table $1 \mathrm{SH}$ may be associated with many genetic syndromes and is particularly frequent and best studied in Turner and Down syndrome.

Table 1 Etiology of subclinical hypothyroidism in children.

- Hashimoto thyroiditis

- Persistent neonatal hyperthyrotropinemia

- Thyroid gene defects and gland dysgenesis

- Nutritional iodine deficiency or excess

- Drugs

- Exposure to ionizing radiations

- Syndromes (i.e. Down, Turner, Williams, Pseudohypoparathyroidism)

- Obesity

- Macro-TSH

- Idiopathic 
In patients with Turner syndrome (TS), $\mathrm{SH}$ is a frequent finding and is mainly related to the presence of HT (25). The natural history of HT-related SH in TS is characterized by increased rate of deterioration of thyroid function (23, 26). One of the largest studies, involving 90 TS patients with HT, reported a progression to overt hypothyroidism in up to $67.7 \%$ of subjects, regardless of the karyotype, over a median period of 4.9 years (27).

In children with Down syndrome (DS) $\mathrm{SH}$ is also frequent, with a prevalence ranging between 25.3 and $60 \%$ (28) and can be diagnosed already in the neonatal period, regardless of prematurity, low birth weight or perinatal risk factors (29).

One of the most common cause of SH in DS patients is autoimmune thyroid disease, especially after the first decade of life (30) and HT is more likely to present with SH in DS, compared to the general population (24).

Other causes of non-autoimmune mild TSH elevation include increased gene dosage for superoxide dismutase-1, resistance to TSH action (31), Zn deficiency (32) or specific TSH setting (33). Thyroid hypoplasia (34), and mild primary thyroid dysfunction peculiar to the syndrome (35) have also been reported.

Several follow-up studies $(30,31,36,37,38)$ indicate a high rate of spontaneous resolution in patients negative for anti-thyroid antibodies (up to 89.7\%) (36), whereas risk factors for progression to overt hypothyroidism include increasing age (30), goiter (36), positive TPO Ab $(30,38)$, and higher baseline TSH concentrations (38).

\section{Obesity}

SH is a common finding in overweight and obese children with a prevalence of $7-23 \%(39,40)$, most often without any other signs of thyroid disease. A few children with obesity and elevated TSH levels have hypoechogenic thyroid gland pattern at ultrasound $(41,42)$, which could represent a feature of thyroid derangement due to obesity itself or an early marker of a seronegative autoimmune thyroiditis. However, autoimmune thyroiditis has seldom been reported as a cause of mild TSH increase in childhood obesity (40). It has been hypothesized that an increase in TSH concentrations may represent an adaptive mechanism aiming to increase energy expenditure (43). In this respect, the presence of an adipose tissue-hypothal amus-pituitary-thyroid axis has been proposed. In this model, leptin secreted by adipocytes might be involved in the cross-talk between adipocytes and hypothalamus, with the aim of increasing the release of TRH and TSH, and the peripheral conversion of T4 into T3 (44). Several other hypothesis have been proposed, including lowgrade inflammation of the thyroid parenchyma (which could also explain common finding of non-autoimmune thyroid hypoechogenicity at ultrasound), a partial failure of the negative pituitary feedback due to thyroid hormone resistance at the pituitary level, loss of function of the TSH-R or iodine deficiency $(40,43)$.

Despite uncertainty regarding the underlying mechanism, the findings that abnormalities in thyroid function mostly normalize after weight loss support the hypothesis that the TSH increase in patients who are obese is reversible and seems to be a consequence rather than a cause of obesity $(44,45,46,47)$. Weight loss may also induce a normalization of parenchymal alterations at thyroid ultrasound in obese patients with no anti-thyroid antibodies (48).

L-T4 treatment in addition to weight management interventions has no beneficial effect on BMI reduction $(49,50)$. Therefore, in the absence of clinical and laboratory evidence of hypothyroidism, therapy with thyroid hormone seems unnecessary.

\section{Neonatal hyperthyrotropinemia and thyroid genetic defects}

In the last two decades, the lowering of cut-off values for TSH in the neonatal screening has resulted in an increased rate of detection of mild, potentially transient, neonatal TSH increase $(51,52,53)$. The cause of neonatal hyperthyrotropinemia and the effects on health outcomes are still unclear.

Isolated hypertirotropinemia may be associated with maternal and neonatal iodine deficiency or excess, drugs, and prematurity (54). Genetic mutations like heterozygous mutation in the gene encoding the TSH receptor (TSHR) or in the gene encoding dual oxidase 2 (DUOX2) have also been associated with SH (54). Simple or compound TSHR heterozygous mutation were detected in up to $30 \%$ of subjects with $\mathrm{SH}$, half of them having neonatal hyperthyrotropinemia, with a high prevalence of firstdegree family history for SH (55). In up to $20 \%$ of the cases neonatal hyperthyrotropinemia can be associated with subtle abnormalities of thyroid gland morphology or volume (56).

Finally, neonatal hyperthyrotropinemia may also be found in the context of complex syndromes, like pseudohypoparathyroidism (57) or brain-lung-thyroid syndrome (58). 
Data on long-term evolution of neonatal $\mathrm{SH}$ are scanty; one study reported that most neonates with mildly elevated TSH levels show progressive normalization of thyroid function, even though in up to $32 \%$ mild TSH increase may persist (59).

In children with $\mathrm{SH}$ due to heterozygous loss-offunction TSHR mutations, data on long-term follow-up suggest that this is a stable compensated condition with an appropriately adjusted set-point for pituitary-thyroid feedback, not requiring replacement therapy $(55,60,61)$.

\section{Drugs, exposure to ionizing radiations and iodine deficiency/excess}

Several drugs such as interferon-alfa (62), amiodarone (63), and antiretrovirals (64) may impair thyroid function. $\mathrm{SH}$ is also frequently observed in children taking antiepileptic drugs (phenobarbital, phenytoin, carbamazepine, and valproic acid) $(62,65)$. Even though the underlying mechanisms are not completely understood, these changes in thyroid function are generally reversible on discontinuation of therapy (61).

Moreover, a transient mild elevation of TSH may also be observed in children treated with thyroid hormone who are undertreated or non-compliant to the treatment or in cases of interaction with other substances (i.e. iron, calcium) (1).

Environmental as well as therapeutic exposure to ionizing radiation during childhood can also cause mild thyroid dysfunction. Although primary hypothyroidism in childhood cancer survivors is a well-known effect, the prevalence of $\mathrm{SH}$ compared with overt hypothyroidism is not yet well defined (66). Noteworthy, both internal (radioactive iodine ${ }^{131} \mathrm{I}$ ) and external irradiation are also associated with an increased risk to develop thyroid cancer. Given the trophic effect exerted by TSH on thyroid epithelial cells, post-radiation SH may further increase the risk of thyroid cancer, with relevant implications for treatment decision in these patients (66).

Finally, chronic low iodine intake may result in mildto-severe $\mathrm{SH}$ as well as in goiter and overt hypothyroidism (67). Interestingly, population studies indicate that $\mathrm{SH}$ may also occur in subjects with high iodine intake (68).

\section{Idiopathic SH}

In children with no definite underlying cause $\mathrm{SH}$ is labeled as idiopathic. The natural course of idiopathic $\mathrm{SH}$ is generally benign with a low risk of progression into overt hypothyroidism. In a large retrospective study, 73.6\% of children with mild SH normalized TSH concentrations in a second measurement within a period of 5 years. Only $8.5 \%$ of subjects exhibited a deterioration of thyroid function requiring levothyroxine treatment and the main predictors of evolution were initial TSH $>7.5 \mathrm{mIU} / \mathrm{L}$ and female gender (10).

In two prospective studies idiopathic $\mathrm{SH}$ was associated with a low rate of evolution into overt hypothyroidism (12\%), and the rate of TSH normalization was 41.3 and 61.9\% after 2- (69) and 5-year follow-up (23), respectively.

Children with idiopathic SH had a lower risk of deterioration in thyroid status over time (11.1 vs $53.1 \%$ ) and higher probability of spontaneous TSH normalization (41.1 vs $21.9 \%$ ) with respect to children with mild HT-related SH after 2 years of follow-up (17). Similarly, in another study thyroid function remained stable over 3 -year observation in the majority of children with idiopathic $\mathrm{SH}(47.5 \%)$ as compared to children with HT-related SH (19.9\%) (16).

\section{Transient or falsely elevated TSH}

A condition of transient increase in serum TSH should always be suspected in cases of isolated $\mathrm{SH}$.

Transient increases in TSH levels can be due to intraindividual or between-laboratory variations.

TSH secretion has a circadian rhythm with a maximum during night and a minimum in the afternoon. Sleep has a suppressive effect on TSH, so that sleep deprivation can lead to higher levels of TSH (70). In females, transient rise in TSH concentrations can also occur in the peri-ovulatory phase (71). In addition to physiological variation, several other factors may affect the assessment of TSH, as macroTSH or interferences with the specific assay (i.e. anti-Ru, heterophilic, and human anti-animal antibodies) (72).

Macro-TSH is characterized by high-molecularweight complexes of TSH (mainly bound to IgG) with low bioactivity, that accumulate in the circulation because of slow clearance, and can be recognized by available immunoassays as hyperthyrotropinemia (73). This has been reported in $0.79 \%$ of subjects with subclinical hypothyroidism (73). The presence of macro-TSH can be screened with the polyethylene glycol (PEG) precipitation method (showing TSH precipitation ratios $>70 \%$ ) or dilution tests, and better characterized by gel filtration chromatography (73).

When approaching a child with SH, clinicians should be aware of the possible interferences and suspect them in 
cases with marked difference in comparison to previous results for the same test or discrepancies with other clinical or biochemical parameters. A low threshold of suspicion should be kept in specific categories of patients (e.g. recent immunization, transfusion, autoimmune disease, monoclonal therapy) who are more prone to develop interfering factors.

Moreover, in order to rule out laboratory problems and transient variations, elevations in TSH concentrations should always be confirmed at least two times, with a second determination in 4 to 12 weeks' time.

To date there is no enough evidence to provide indications on the specific management of children with transient elevation of TSH.

\section{Health consequences of SH and effects of thyroid hormone treatment}

In children, well-designed randomized clinical trials and large prospective observational studies have not been performed, and thus, the potential effects of persistent $\mathrm{SH}$ on health outcomes as well as the need for L-T4 treatment are still a matter of debate. The main recent studies on the effects of persistent $\mathrm{SH}$ (both mild or severe) on growth and cardio-metabolic outcomes in cohorts of at least 20 children are summarized in Table 2 .

\section{Linear growth and bone health}

Thyroid hormones play a key role in promoting linear growth, by acting directly on bones or by influencing the growth hormone-insulin-like growth factor 1 axis (GH-IGF-1). So far, only a few studies have evaluated the effects of SH and/or L-T4 treatment on linear growth.

Normal height and growth velocity were documented in a prospective study on a large cohort of 92 children with untreated mild idiopathic SH lasting from 2 years (69). However, in a series of 88 children and adolescents with mild or severe non-autoimmune $\mathrm{SH}$, short stature was detected in $19.3 \%$ of the subjects, with no association with the degree of the increase in TSH levels or the presence of morphological abnormalities at thyroid ultrasound. It has to be outlined that this study also included children referred for growth impairment (42). In another cohort of children with untreated mild idiopathic SH lasting from 2 to 9 years, linear growth, bone maturation and IGF-1 concentrations were normal and comparable to healthy matched controls. In this series, $22 \%$ of subjects presented at study entry with familial short stature, but growth and bone maturation progressed normally during follow-up (74). Finally, in prepubertal children with heterozygous TSHR mutation no differences in height and bone maturation were detected between treated severe and untreated mild subjects (55).

Accordingly, recent data from two prospective studies did not show any significant change in height and linear growth after 2-year L-T4 treatment in children with mild idiopathic SH $(75,76)$.

Even in children with autoimmune SH, normal height and growth velocity were documented over a follow-up of 5 years in those who did not progress to overt hypothyroidism (21).

In another study evaluating HT-related SH associated with other autoimmune diseases such as type 1 diabetes mellitus (77), short stature was observed only in patients with severe $\mathrm{SH}$ (TSH $>50 \mathrm{mU} / \mathrm{L}$ and $\mathrm{T} 4$ levels at the low end of the reference range). In these patients, 1-year L-T4 treatment was effective in improving growth rate (77).

Data on skeletal health in children and adolescents with SH are scanty, and do not show abnormalities in biochemical markers of bone metabolism, lumbar bone mineral density (BMD) and ultrasound parameters of bone quality $(55,78,79)$. Untreated children with mild SH due to heterozygous TSHR mutations showed normal $\mathrm{BMD}$, comparable to severe SH children receiving L-T4 treatment (55). Moreover, no appreciable effects after L-T4 therapy on BMD were detected among children with autoimmune SH (78).

\section{Neurocognitive outcome}

Thyroid hormones influence fetal and postnatal brain development and function, by regulating neuronal migration, differentiation, myelination and synaptogenesis (80). Untreated overt hypothyroidism before the age of 3 years, when thyroid hormone play a pivotal role, is well-known to cause mental retardation. Whether neonates with a mild TSH increase (TSH concentrations between 6-20 mU/L) but normal FT4 concentration may have subtle brain damage is still unclear. In a large cohort study, Lain et al. (81) found a worse neurocognitive outcome in school-age children whose neonatal screening TSH concentrations were between the 99.5th and 99.9th percentiles (about 9 and $14 \mathrm{mU} / \mathrm{L}$ in whole blood). Conversely, in a Belgian cohort, mild elevation of neonatal TSH was not associated with neurodevelopment impairment at preschool age $(82,83)$.

Concern exists regarding long-term health effects of SH particularly in growing children in whom subtle 


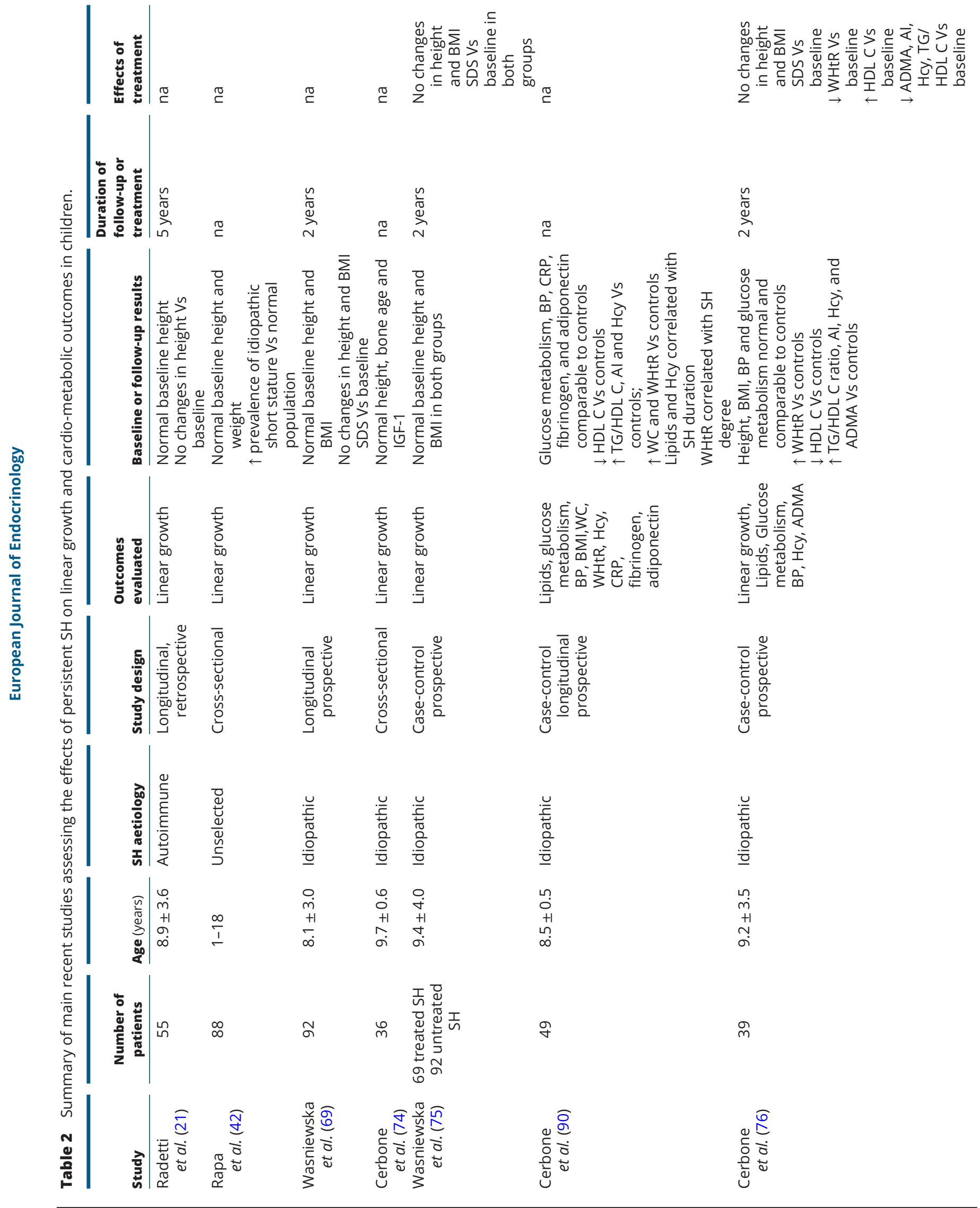


$\stackrel{\pi}{\complement}$

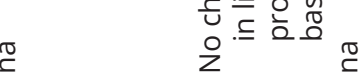

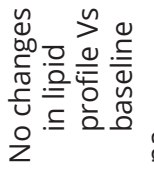

2

$\frac{2}{2}$

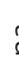

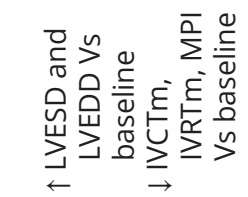

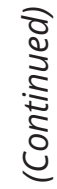

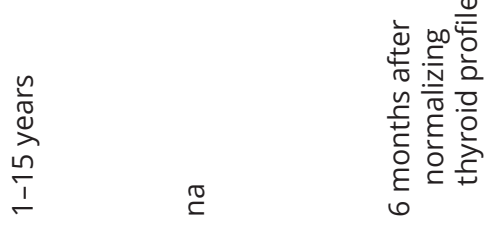

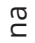

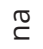

$\stackrel{0}{\check{5}}$

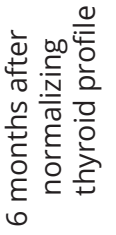

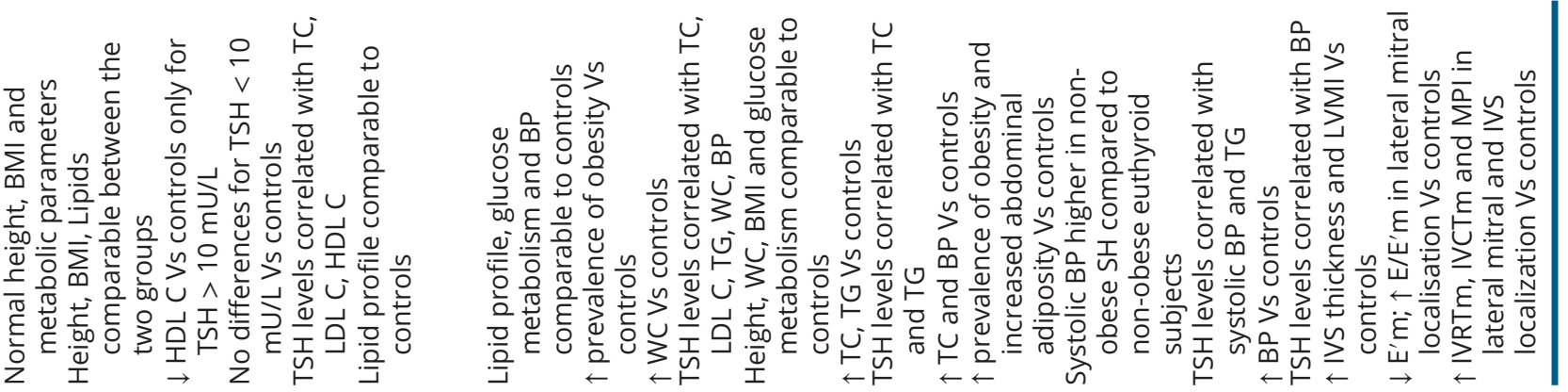

辛
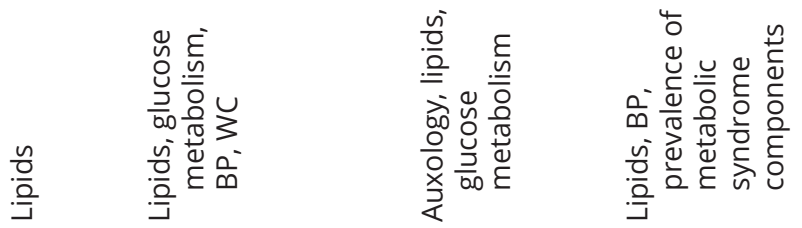

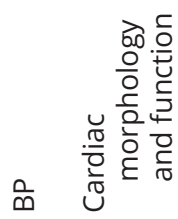

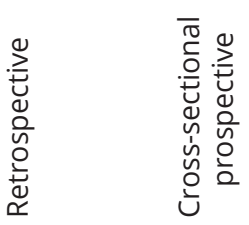

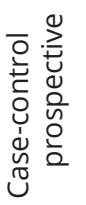
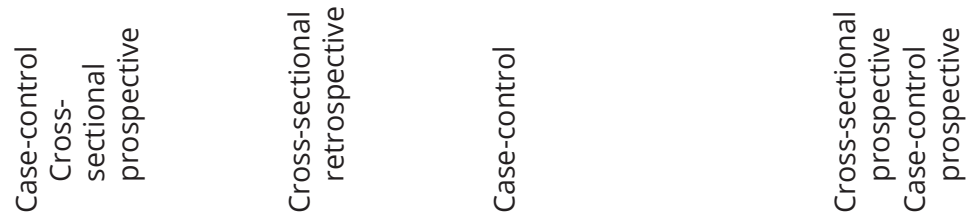

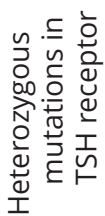
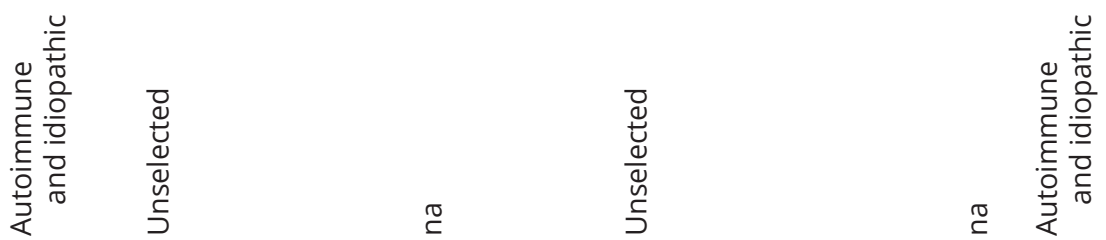

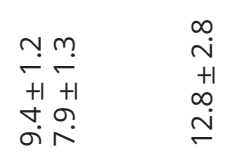

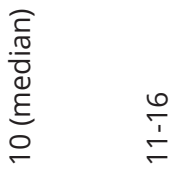

$\stackrel{\overparen{T}}{\complement}$

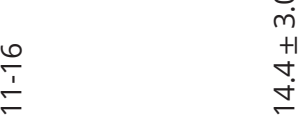

$\stackrel{0}{m}$
+1
+
$\stackrel{+}{+}$

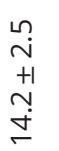

$\begin{array}{ll}\stackrel{m}{m} & \stackrel{m}{r} \\ +1 & ++ \\ \check{r} & m \\ \check{r} & \stackrel{\circ}{r}\end{array}$

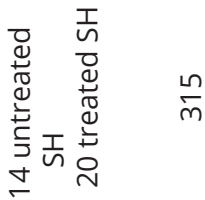

$\stackrel{n}{m} \quad$ ำ

苋

$\stackrel{m}{\leftarrow}$

$\stackrel{\Xi}{\sim} \bar{m}$

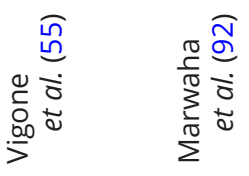

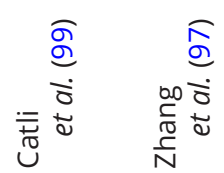

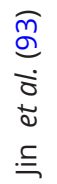

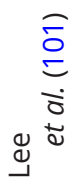

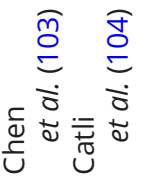



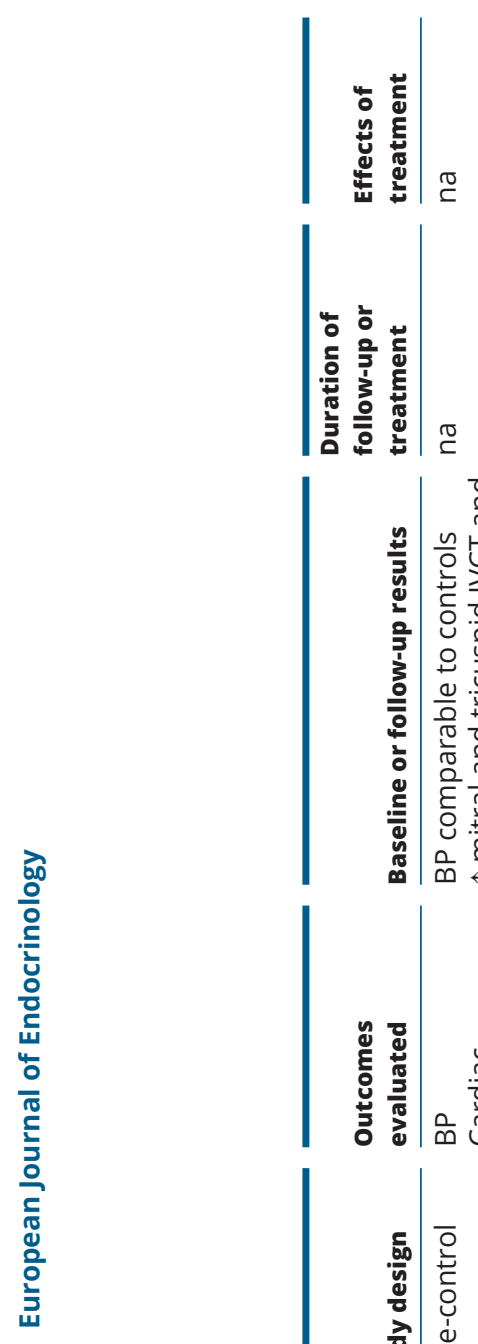

abnormalities may easily affect neurocognitive development (11).

In the NHANES III study cognitive functions have been found to be normal in mild $\mathrm{SH}$ adolescents, with even better performances than euthyroid subjects in block design and reading (9). However, other studies reported an association between mild increases in TSH concentrations and subtle alterations in verbal comprehension, immediate and long-term recall (84) and attention problems $(85,86)$.

In addition, subtle changes in auditory event-related potentials evaluated trough auditory stimuli applied during the electroencephalography recordings, reflecting memory tasks and attentional process, were detected in a small cohort of children with SH despite normal cognitive functions (87). Whether these early neuro-electrical variances may result, over time, in clinical neurocognitive alterations need to be further evaluated.

Moreover, in one study 6 months of L-T4 treatment were associated with an improvement in visual and verbal memory as well as in verbal recall scores in children with mild SH (88).

Conversely, in a prospective case-control study evaluating neuropsychological outcome among children with mild SH, no differences were detected in verbal, performance and full-scale intellectual quotient (IQ) scores, as well as in degree of depression and behavioral problems, in comparison to healthy controls matched for socioeconomic status (74). These data were further confirmed by a recent study on children with mild TSH resistance. Indeed, IQ scores in untreated children with mild SH due to heterozygous TSHR mutation were normal and comparable to children with severe $\mathrm{SH}$ treated with L-T4 (55).

Accordingly, a recent prospective study in children with mild and long-lasting idiopathic SH documented normal global, verbal and performance IQ scores, in comparison to matched controls and no changes on neurocognitive function after 2-year L-T4 treatment (89).

\section{Cardio-metabolic outcomes}

Although the majority of the studies do not show overt dyslipidemia, there is evidence that children with SH may develop subtle pro-atherogenic abnormalities in lipid profile $(90,91,92)$. In fact, unfavorable levels in HDL cholesterol (HDL C) have been demonstrated in both severe (TSH >10 mU/L) (92) and mild (TSH $<10 \mathrm{mU} / \mathrm{L})$ untreated SH $(90,91)$. Moreover, the results of a recent large national survey revealed higher concentrations of total cholesterol and triglycerides in $\mathrm{SH}$, compared to 
euthyroid subjects (93). Similarly, in a large observational study, children and adolescents with mild SH $(n=228)$, showed higher total cholesterol and non-HDL $C$ levels than euthyroid controls $(n=1215)$ with a positive association with TSH levels (94). A significant correlation between TSH concentrations, triglycerides $(93,95,96)$, total cholesterol $(93,96)$ and non-HDL C $(97,98)$ has also been reported in other studies.

Conversely, in a study including 27 children with mild or severe $\mathrm{SH}$, lipid profile was comparable to controls at baseline and did not change after achievement of euthyroidism with L-T4 treatment (99). However, in a longitudinal study on 49 children with mild untreated $\mathrm{SH}$, we found decreased HDL C and increased triglycerides/ HDL C (which estimates small dense low-density lipoproteins and is predictor of increased arterial stiffness) and total/HDL C (also known as atherogenic index), in comparison to healthy controls, even after correction for indexes of adiposity (90). In this study lipid parameters correlated with duration of $\mathrm{SH}$ (90). In a subsequent study, 39 out of these 49 children were treated with L-T4 for 2 years and a significant increase in HDL C, and decrease in triglycerides/HDL $\mathrm{C}$ ratio and atherogenic index was observed (76). In this regard, it is worth to mention that a recent meta-analysis of 12 randomized controlled trials involving a total 940 adult patients with $\mathrm{SH}$ suggested that L-T4 treatment has a beneficial effect on lipid profile even in patients with mild SH (100).

As discussed above, an isolated mild increase in TSH levels is a common finding in overweight and obese children and weight reduction is generally associated with a decrease in TSH concentrations, suggesting that obesity represents a cause more than a consequence of increased TSH concentrations $(43,47)$. Noteworthy, in normal weight children with persistent $\mathrm{SH}$, higher indexes of visceral adiposity (i.e. increase in waist circumference and waist-to-height ratio) have been documented with respect to euthyroid controls $(90,97,101)$, despite not being associated with increased BMI $(55,69,74,90)$. Furthermore, L-T4 treatment exerts beneficial effects on visceral adiposity as documented by a significant decrease in waist-to-height ratio after 2 years of treatment (76) with no changes in BMI $(75,76)$.

A few studies reported an association between TSH concentrations and blood pressure values (101, 102, 103) and a tendency to develop systolic and diastolic hypertension in children with $\mathrm{SH}$ compared to euthyroid subjects (103). Conversely, other studies $(76,104,105)$ did not show any difference in blood pressure between mild or severe SH and euthyroid subjects. Moreover, 2 years of
L-T4 treatment were not associated with changes in both systolic and diastolic blood pressure (76).

TSH levels have been associated with subtle alterations in fasting glucose and insulin levels and Homeostasis Model Assessment (HOMA) index (95). However, in the few pediatric studies available, no relationship has been reported between $\mathrm{SH}$ and altered glucose metabolism (76, $90,93,106)$.

Higher homocysteine levels, which are thought to be an independent risk factor for CV disease (107), have been reported in children with mild $\mathrm{SH}$, with respect to euthyroid controls, in some $(76,90)$ but not all studies (108). In addition, higher levels of asymmetric dimethylarginine (ADMA), acting as a competitive inhibitor of endothelial nitric oxide synthase, were found in mild SH patients compared to controls (76), despite no differences in other early markers of endothelial dysfunction and atherosclerotic changes such as flow mediated dilation and carotid intima-media thickness (76, 109). Two years of L-T4 treatment were associated with an improvement in ADMA concentrations, and with a trend towards a reduction in homocysteine levels (76).

Finally, TSH and thyroid hormones influence cardiac contractility, myocardial oxygen consumption, cardiac output, thus contributing to the maintenance of cardiovascular homeostasis. So far only few studies evaluated cardiac consequences of $\mathrm{SH}$ in children. Compared to euthyroid controls, children with mild or severe $\mathrm{SH}$ showed an increase in interventricular septum thickness and left ventricular mass index (104) and subclinical ventricular diastolic dysfunction $(104,105)$, which are reverted by L-T4 treatment (104).

In summary, available data suggest that children with long-standing SH may develop a cluster of subtle pro-atherogenic risk factors, such as unfavorable changes in lipid profile, increase in visceral adiposity and in early markers of atherosclerotic changes, which might predispose them to develop cardiovascular disease in the future. However, further long-term controlled studies are needed to clarify whether persistent $\mathrm{SH}$ is associated with CV abnormalities and whether a trial of L-T4 therapy will be effective in preventing $\mathrm{CV}$ morbidity.

\section{Management of children with SH}

In childhood and adolescence the management of $\mathrm{SH}$ is controversial due to the lack of high-quality data on longterm outcomes. A proposal of management is illustrated in Fig. 1. 


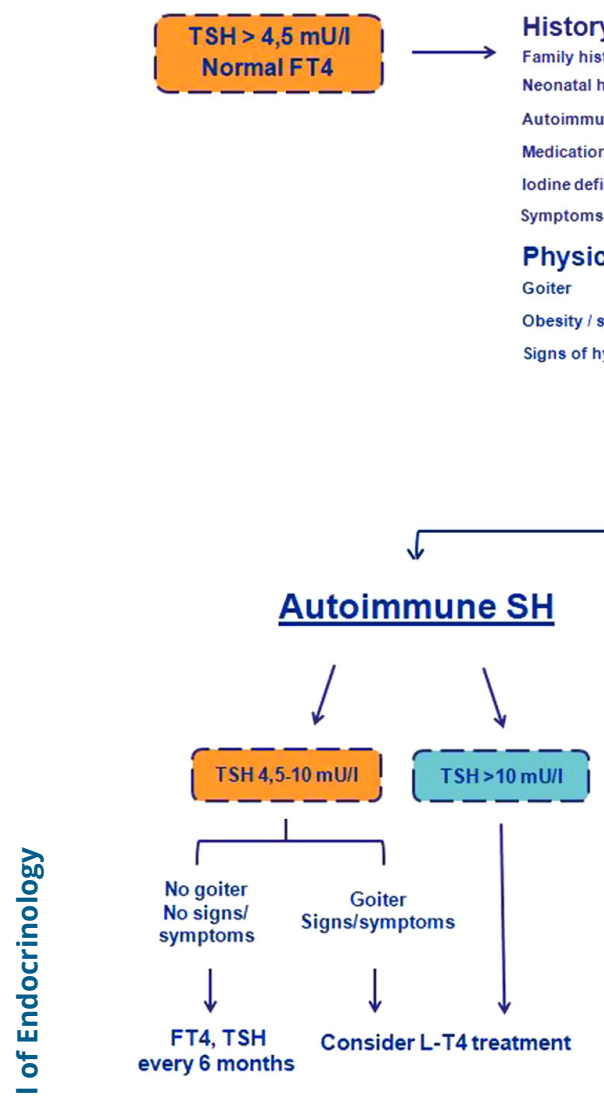

Family history of thyroid or autoimmune diseases eonatal hyperthyrotropinemia toimmune/genetic disorders hysical examination sity / syndromic features s of hypothyroidism

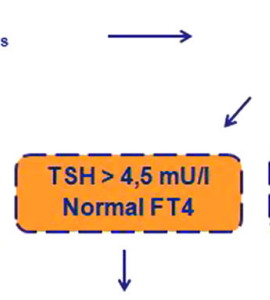

Anti-thyroid antibodies

Thyroid ultrasound (in selected cases)

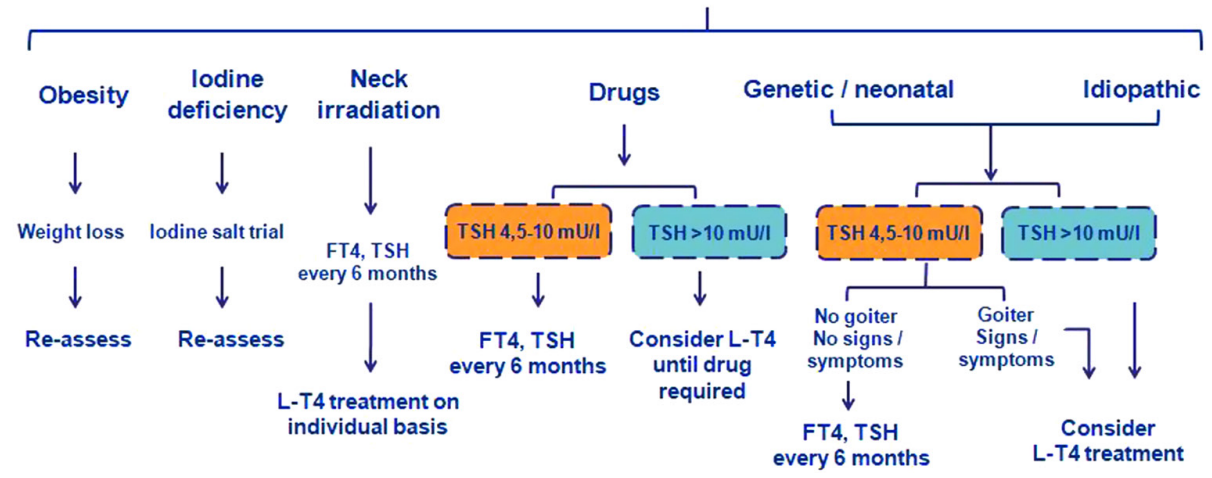

Non autoimmune SH anti-thyroid antibodies after 4-12 weeks

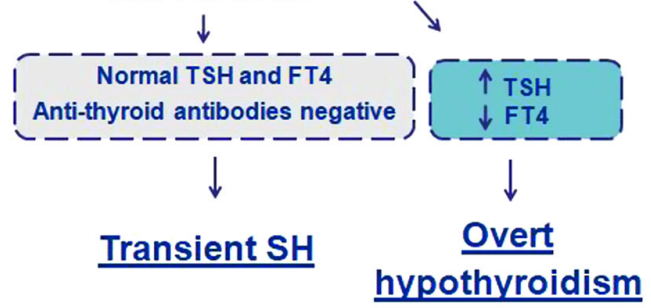

$\downarrow$

Thyroid ultrasound

Look for aetiology and treat

\section{Figure 1}

Management of subclinical hypothyroidism in children.

When approaching a child with $\mathrm{SH}$ the first step is to re-evaluate TSH concentrations after 4-12 weeks depending on the degree of TSH elevation. In the same confirmatory blood test, it is advisable to check for the presence of anti-thyroid antibodies. Thyroid ultrasound plays a role in evaluating possible gland morphological or structural abnormalities and thus it represents an important tool in the work-up of persistent forms of $\mathrm{SH}$, especially when no clear causes are identified. Indeed, thyroid ultrasound could be avoided in the initial work-up of those cases with a clear-cut etiology that does not require morpho-structural assessment of the thyroid gland (i.e. obesity, drugs, macro-TSH and familial nongoitrous conditions).

Family and personal history, as well as clinical examination are of paramount importance for establishing further diagnostic work-up. Family history should focus on the presence of $\mathrm{SH}$, goiter, and endocrine, genetic, or autoimmune conditions in other family members. Personal history should investigate the presence of neonatal SH, autoimmune and/or genetic conditions, use of drugs/substances interfering with thyroid function, iodine intake or exposure to ionizing radiation.

Physical examination should be aimed at recognizing signs of hypothyroidism, goiter and dysmorphic features suggesting genetic conditions.

Specific genetic analysis should be deserved to familial cases of $\mathrm{SH}$ and/or syndromic conditions. Urinary iodine excretion is a good marker for population iodine status, with values between 100 and $299 \mu \mathrm{g} / \mathrm{L}$ suggesting optimal iodine nutrition in school-aged children; however, it is not useful for individual assessment (67). Indeed, spot urinary iodine concentration may vary widely from day to day and it only estimates iodine intake over the past few days (67). Therefore, careful questions on dietary intake are required to establish iodine deficient status.

Once the diagnostic work-up has been completed, the following management strictly depends on the underlying cause of SH. Despite the lack of strong evidence on the beneficial effects of replacement therapy, similar to what recommended for adults L-T4 treatment should be considered for autoimmune or non-autoimmune forms of 
SH when TSH concentrations are above $10 \mathrm{mU} / \mathrm{L}$. In mild forms, current data in general justify to advice against treatment. However, a trial with L-T4 can be considered in selected cases of persistent SH experiencing relevant signs or symptoms of hypothyroidism. It remained to be defined whether a trial with L-T4 might be also considered in cases of persistent $\mathrm{SH}$ experiencing $\mathrm{CV}$ risk factors (dyslipidemia and or cardiovascular dysfunction), in order to reduce $\mathrm{CV}$ morbidity.

In HT a treatment with L-T4 should also be considered in case of thyroid gland enlargement $(110,111)$ or nodular goiter (7). Benefits and possible effects of L-T4 treatment must be always discussed with the family and treatment should be continued only if it results in clear beneficial effects.

Furthermore, treatment with L-T4 may be justified in patients with $\mathrm{SH}$ and a history of neck irradiation, in order to reduce the theoretical increased risk of thyroid cancer due to the trophic effect of TSH on thyroid epithelial cells (66), in particular in those children with evidence of thyroid nodule (112) or with other risk factors such as young age at radiation exposure, high dose of radiations, personal and familial susceptibility (113).

In particular cases, euthyroidism can be achieved after reverting the cause of SH like weight loss in overweight/ obese subjects, iodine supplementation in cases with iodine deficiency or discontinuation of a specific drug when possible.

In subjects with mild SH and no signs or symptoms of hypothyroidism regular evaluation of thyroid function is indicated. Careful monitoring is particularly recommended in subjects with chromosomal abnormalities (TS and DS) or autoimmune conditions, due to the increased risk of progression into overt thyroid dysfunction. The timing of clinical and laboratory monitoring will depend on the underlying cause and should be tailored on individual patient's factors.

Although the effects of $\mathrm{SH}$ on neurocognitive function are still not completely defined, in view of the important role played by thyroid hormone in brain development, infants and children below two years of age deserve careful monitoring. In neonates, the European Society for Pediatric Endocrinology (ESPE) guidelines (114) recommend to start L-T4 treatment if venous TSH concentration is persistently above $20 \mathrm{mIU} / \mathrm{L}$, even if serum FT 4 concentration is normal. For TSH concentration between 6 and $20 \mathrm{mIU} / \mathrm{L}$, but normal FT4 levels, the decision to start treatment should be individualized as there are insufficient evidence to recommend for or against treatment. In healthy babies with mild SH lasting more than 3-4 weeks, clinicians should discuss with the family whether to repeat thyroid profile after additional 1-2 weeks, especially for values around $10 \mathrm{mIU} / \mathrm{L}$ or to start treatment and retest off treatment after the age of 3 years, or even earlier (114).

The decision to start treatment with L-T4 depends on multiple factors, such as the age of the patient, the duration of the thyroid dysfunction, the trend of TSH values, the etiology, the presence of syndromes and/ or other pathologies, and the parents' choice and reliability (54).

Finally, in cases with known genetic etiology, the management of $\mathrm{SH}$ is also controversial. In patients heterozygous for TSHR mutations, $\mathrm{SH}$ is generally considered a compensated thyroid dysfunction with an appropriately adjusted set point for pituitary-thyroid feedback and does not require treatment. Nevertheless, if heterozygous mutations of TSHR are detected in patients belonging to special categories (preterm infants, small for gestational age neonates, infants born after multiple pregnancies and/or conceived by assisted reproduction techniques), L-T4 supplementation might be considered (55). In contrast, in carriers of biallelic mutations, a trend towards an increase in TSH levels with a concomitant decline in FT4 concentrations has been observed, suggesting the need for long-term follow-up and/or L-T4 therapy (54).

\section{Conclusions and future perspectives}

The best management of mild SH in children is still not clear. So far, there is no evidence that mild untreated SH is associated with alterations in health outcomes. However, subtle abnormalities in early $\mathrm{CV}$ risk factors and deficits in specific cognitive domains have been documented, and a beneficial effect of L-T4 treatment on these abnormalities has been reported. Nevertheless, these findings are not sufficient to recommend L-T4 treatment in all children with mild $\mathrm{SH}$ and need to be further confirmed by adequately powered controlled studies.

In the meantime, the decision to initiate therapy should be based on individual factors, and the evaluation of early CV risk biomarkers and neurocognitive assessment in selected children with SH may help in the decision regarding treatment. In subjects who do not meet criteria for treatment, regular clinical evaluation and thyroid function monitoring is advisable to early identify those children who may benefit from therapy. 
Improving our knowledge on health consequences of untreated $\mathrm{SH}$ in childhood will help to better understand the management of this condition and to develop specific monitoring or treatment strategies.

\section{Declaration of interest}

The authors declare that there is no conflict of interest that could be perceived as prejudicing the impartiality of this review.

\section{Funding}

This research did not receive any specific grant from any funding agency in the public, commercial or not-for-profit sector.

\section{References}

1 Biondi B \& Cooper DS. The clinical significance of subclinical thyroid dysfunction. Endocrine Reviews 200829 76-131. (https://doi. org/10.1210/er.2006-0043)

2 Önsesveren I, Barjaktarovic M, Chaker L, de Rijke YB, Jaddoe VWV, van Santen HM, Visser TJ, Peeters RP \& Korevaar TIM. Childhood thyroid function reference ranges and determinants: a literature overview and a prospective cohort study. Thyroid 201727 1360-1369. (https://doi.org/10.1089/thy.2017.0262)

3 Biondi B, Cappola AR \& Cooper DS. Subclinical hypothyroidism: a review. JAMA 2019322 153-160. (https://doi.org/10.1001/ jama.2019.9052)

4 Stott DJ, Rodondi N, Bauer DC \& TRUST Study Group. Thyroid hormone therapy for older adults with subclinical hypothyroidism. New England Journal of Medicine 2017377 e20. (https://doi. org/10.1056/NEJMc1709989)

5 Feller M, Snel M, Moutzouri E, Bauer DC, de Montmollin M, Aujesky D, Ford I, Gussekloo J, Kearney PM, Mooijaart S et al. Association of thyroid hormone therapy with quality of life and thyroid-related symptoms in patients with subclinical hypothyroidism: a systematic review and meta-analysis. JAMA 2018 320 1349-1359. (https://doi.org/10.1001/jama.2018.13770)

6 Garber JR, Cobin RH, Gharib H, Hennessey JV, Klein I, Mechanick JI, Pessah-Pollack R, Singer PA, Woeber KA \& American Association of Clinical Endocrinologists and American Thyroid Association Taskforce on Hypothyroidism in Adults. Clinical practice guidelines for hypothyroidism in adults: cosponsored by the American Association of Clinical Endocrinologists and the American Thyroid Association. Thyroid 201222 1200-1235. (https://doi.org/10.1089/ thy.2012.0205)

7 Pearce SH, Brabant G, Duntas LH, Monzani F, Peeters RP, Razvi S \& Wemeau JL. 2013 ETA guideline: management of subclinical hypothyroidism. European Thyroid Journal 20132 215-228. (https:// doi.org/10.1159/000356507)

8 Peeters RP. Subclinical hypothyroidism. New England Journal of Medicine 2017377 1404. (https://doi.org/10.1056/NEJMc1709853)

9 Wu T, Flowers JW, Tudiver F, Wilson JL \& Punyasavatsut N. Subclinical thyroid disorders and cognitive performance among adolescents in the United States. BMC Pediatrics 20066 12. (https:// doi.org/10.1186/1471-2431-6-12)

10 Lazar L, Frumkin RB, Battat E, Lebenthal Y, Phillip M \& Meyerovitch J. Natural history of thyroid function tests over 5 years in a large pediatric cohort. Journal of Clinical Endocrinology and Metabolism 2009 94 1678-1682. (https://doi.org/10.1210/jc.2008-2615)

11 Salerno M, Capalbo D, Cerbone M \& De Luca F. Subclinical hypothyroidism in childhood - current knowledge and open issues. Nature Reviews: Endocrinology 201612 734-746. (https://doi. org/10.1038/nrendo.2016.100)

12 Monzani A, Prodam F, Rapa A, Moia S, Agarla V, Bellone S \& Bona G. Endocrine disorders in childhood and adolescence. Natural history of subclinical hypothyroidism in children and adolescents and potential effects of replacement therapy: a review. European Journal of Endocrinology 2013168 R1-R11. (https://doi.org/10.1530/EJE-12-0656)

13 O'Grady MJ \& Cody D. Subclinical hypothyroidism in childhood. Archives of Disease in Childhood 201196 280-284. (https://doi. org/10.1136/adc.2009.181800)

14 Lazarus J, Brown RS, Daumerie C, Hubalewska-Dydejczyk A, Negro R \& Vaidya B. 2014 European Thyroid Association guidelines for the management of subclinical hypothyroidism in pregnancy and in children. European Thyroid Journal 20143 76-94. (https://doi. org/10.1159/000362597)

15 Demirbilek H, Kandemir N, Gonc EN, Ozon A \& Alikasifoglu A. Assessment of thyroid function during the long course of Hashimoto's thyroiditis in children and adolescents. Clinical Endocrinology 200971 451-454. (https://doi.org/10.1111/j.13652265.2008.03501.x)

16 Radetti G, Maselli M, Buzi F, Corrias A, Mussa A, Cambiaso P, Salerno M, Cappa M, Baiocchi M, Gastaldi R et al. The natural history of the normal/mild elevated TSH serum levels in children and adolescents with Hashimoto's thyroiditis and isolated hyperthyrotropinaemia: a 3-year follow-up. Clinical Endocrinology 201276 394-398. (https://doi.org/10.1111/j.13652265.2011.04251.x)

17 Aversa T, Valenzise M, Corrias A, Salerno M, De Luca F, Mussa A, Rezzuto M, Lombardo F \& Wasniewska M. Underlying Hashimoto's thyroiditis negatively affects the evolution of subclinical hypothyroidism in children irrespective of other concomitant risk factors. Thyroid 201525 183-187. (https://doi.org/10.1089/ thy.2014.0235)

18 Aversa T, Corrias A, Salerno M, Tessaris D, Di Mase R, Valenzise M, Corica D, De Luca F \& Wasniewska M. Five-year prospective evaluation of thyroid function test evolution in children with Hashimoto's thyroiditis presenting with either euthyroidism or subclinical hypothyroidism. Thyroid 201626 1450-1456. (https:// doi.org/10.1089/thy.2016.0080)

19 Lee YJ, Jung SY, Jung HW, Kim SY, Lee YA, Lee SY, Shin CH \& Yang SW. Unfavorable course of subclinical hypothyroidism in children with Hashimoto's thyroiditis compared to those with isolated non-autoimmune hyperthyrotropinemia. Journal of Korean Medical Science 201732 124-129. (https://doi.org/10.3346/ jkms.2017.32.1.124)

20 Gopalakrishnan S, Chugh PK, Chhillar M, Ambardar VK, Sahoo M \& Sankar R. Goitrous autoimmune thyroiditis in a pediatric population: a longitudinal study. Pediatrics 2008122 e670-e674. (https://doi. org/10.1542/peds.2008-0493)

21 Radetti G, Gottardi E, Bona G, Corrias A, Salardi S, Loche S \& Study Group for Thyroid Diseases of the Italian Society for Pediatric Endocrinology and Diabetes (SIEDP/ISPED). The natural history of euthyroid Hashimoto's thyroiditis in children. Journal of Pediatrics 2006149 827-832. (https://doi.org/10.1016/j.jpeds.2006.08.045)

22 Wasniewska M, Corrias A, Salerno M, Mussa A, Capalbo D, Messina MF, Aversa T, Bombaci S, De Luca F \& Valenzise M. Thyroid function patterns at Hashimoto's thyroiditis presentation in childhood and adolescence are mainly conditioned by patients' age. Hormone Research in Paediatrics 201278 232-236. (https://doi. org/10.1159/000343815)

23 Wasniewska M, Aversa T, Salerno M, Corrias A, Messina MF, Mussa A, Capalbo D, De Luca F \& Valenzise M. Five-year prospective evaluation of thyroid function in girls with subclinical mild hypothyroidism of different etiology. European Journal of Endocrinology 2015173 801-808. (https://doi.org/10.1530/EJE-150484) 
24 Aversa T, Salerno M, Radetti G, Faienza MF, Iughetti L, Corrias A, Predieri B, Mussa A, Mirabelli S, De Luca F et al. Peculiarities of presentation and evolution over time of Hashimoto's thyroiditis in children and adolescents with Down's syndrome. Hormones 201514 410-416. (https://doi.org/10.14310/horm.2002.1574)

25 Gawlik A, Gawlik T, Januszek-Trzciakowska A, Patel H \& MaleckaTendera E. Incidence and dynamics of thyroid dysfunction and thyroid autoimmunity in girls with Turner's syndrome: a long-term follow-up study. Hormone Research in Paediatrics 201176 314-320. (https://doi.org/10.1159/000331050)

26 Wasniewska M, Salerno M, Corrias A, Mazzanti L, Matarazzo P, Corica D, Aversa T, Messina MF, De Luca F \& Valenzise M. The evolution of thyroid function after presenting with Hashimoto thyroiditis is different between initially euthyroid girls with and those without Turner syndrome. Hormone Research in Paediatrics 2016 86 403-409. (https://doi.org/10.1159/000452722)

27 Aversa T, Messina MF, Mazzanti L, Salerno M, Mussa A, Faienza MF, Scarano E, De Luca F \& Wasniewska M. The association with Turner syndrome significantly affects the course of Hashimoto's thyroiditis in children, irrespective of karyotype. Endocrine $2015 \mathbf{5 0} 777-782$. (https://doi.org/10.1007/s12020-014-0513-6)

28 King K, O'Gorman C \& Gallagher S. Thyroid dysfunction in children with Down syndrome: a literature review. Irish Journal of Medical Science 2014183 1-6. (https://doi.org/10.1007/s11845-013-0994-y)

29 van Trotsenburg AS, Vulsma T, van Santen HM, Cheung W \& de Vijlder JJ. Lower neonatal screening thyroxine concentrations in down syndrome newborns. Journal of Clinical Endocrinology and Metabolism 200388 1512-1515. (https://doi.org/10.1210/jc.2002021303)

30 Iughetti L, Predieri B, Bruzzi P, Predieri F, Vellani G, Madeo SF, Garavelli L, Biagioni O, Bedogni G \& Bozzola M. Ten-year longitudinal study of thyroid function in children with Down's syndrome. Hormone Research in Paediatrics 201482 113-121. (https:// doi.org/10.1159/000362450)

31 Rubello D, Pozzan GB, Casara D, Girelli ME, Boccato S, Rigon F, Baccichetti C, Piccolo M, Betterle C \& Busnardo B. Natural course of subclinical hypothyroidism in Down's syndrome: prospective study results and therapeutic considerations. Journal of Endocrinological Investigation 199518 35-40. (https://doi.org/10.1007/BF03349694)

32 Ertek S, Cicero AF, Caglar O \& Erdogan G. Relationship between serum zinc levels, thyroid hormones and thyroid volume following successful iodine supplementation. Hormones 20109 263-268. (https://doi.org/10.14310/horm.2002.1276)

33 Meyerovitch J, Antebi F, Greenberg-Dotan S, Bar-Tal O \& Hochberg Z. Hyperthyrotropinaemia in untreated subjects with Down's syndrome aged 6 months to 64 years: a comparative analysis. Archives of Disease in Childhood 201297 595-598. (https://doi.org/10.1136/ archdischild-2011-300806)

34 Sarici D, Akin MA, Kurtoglu S, Gunes T, Ozturk MA \& Akcakus M. Thyroid functions of neonates with Down syndrome. Italian Journal of Pediatrics 201238 44. (https://doi.org/10.1186/1824-7288-38-44)

35 van Trotsenburg AS, Kempers MJ, Endert E, Tijssen JG, de Vijlder JJ \& Vulsma T. Trisomy 21 causes persistent congenital hypothyroidism presumably of thyroidal origin. Thyroid 200616 671-680. (https:// doi.org/10.1089/thy.2006.16.671)

36 Claret C, Goday A, Benaiges D, Chillarón JJ, Flores JA, Hernandez E, Corretger JM \& Cano JF. Subclinical hypothyroidism in the first years of life in patients with Down syndrome. Pediatric Research 201373 674-678. (https://doi.org/10.1038/pr.2013.26)

37 Gibson PA, Newton RW, Selby K, Price DA, Leyland K \& Addison GM. Longitudinal study of thyroid function in Down's syndrome in the first two decades. Archives of Disease in Childhood $200590574-578$. (https://doi.org/10.1136/adc.2004.049536)

38 Pepe G, Corica D, De Sanctis L, Salerno M, Faienza MF, Tessaris D, Tuli G, Scala I, Penta L, Alibrandi A et al. Prospective evaluation of autoimmune and non-autoimmune subclinical hypothyroidism in
Down syndrome children. European Journal of Endocrinology 2020182 385-392. (https://doi.org/10.1530/EJE-19-0823)

39 Niranjan U \& Wright NP. Should we treat subclinical hypothyroidism in obese children? BMJ 2016352 i941. (https://doi.org/10.1136/bmj. i941)

40 Pacifico L, Anania C, Ferraro F, Andreoli GM \& Chiesa C. Thyroid function in childhood obesity and metabolic comorbidity. Clinica Chimica Acta; International Journal of Clinical Chemistry 2012413 396-405. (https://doi.org/10.1016/j.cca.2011.11.013)

41 Radetti G, Kleon W, Buzi F, Crivellaro C, Pappalardo L, di Iorgi N $\&$ Maghnie M. Thyroid function and structure are affected in childhood obesity. Journal of Clinical Endocrinology and Metabolism 200893 4749-4754. (https://doi.org/10.1210/jc.2008-0823)

42 Rapa A, Monzani A, Moia S, Vivenza D, Bellone S, Petri A, Teofoli F, Cassio A, Cesaretti G, Corrias A et al. Subclinical hypothyroidism in children and adolescents: a wide range of clinical, biochemical, and genetic factors involved. Journal of Clinical Endocrinology and Metabolism 200994 2414-2420. (https://doi.org/10.1210/jc.20090375)

43 Reinehr T. Thyroid function in the nutritionally obese child and adolescent. Current Opinion in Pediatrics 201123 415-420. (https:// doi.org/10.1097/MOP.0b013e328344c393)

44 Yavuz S, Salgado Nunez Del Prado S \& Celi FS. Thyroid hormone action and energy expenditure. Journal of the Endocrine Society 20193 1345-1356. (https://doi.org/10.1210/js.2018-00423)

45 Grandone A, Santoro N, Coppola F, Calabrò P, Perrone L \& Del Giudice EM. Thyroid function derangement and childhood obesity: an Italian experience. BMC Endocrine Disorders 201010 8. (https:// doi.org/10.1186/1472-6823-10-8)

46 Marras V, Casini MR, Pilia S, Carta D, Civolani P, Porcu M, Uccheddu AP \& Loche S. Thyroid function in obese children and adolescents. Hormone Research in Paediatrics 201073 193-197. (https://doi.org/10.1159/000284361)

47 Wolters B, Lass N \& Reinehr T. TSH and free triiodothyronine concentrations are associated with weight loss in a lifestyle intervention and weight regain afterwards in obese children. European Journal of Endocrinology 2013168 323-329. (https://doi. org/10.1530/EJE-12-0981)

48 Licenziati MR, Valerio G, Vetrani I, De Maria G, Liotta F \& Radetti G. Altered thyroid function and structure in children and adolescents who are overweight and obese: reversal after weight loss. Journal of Clinical Endocrinology and Metabolism 2019104 2757-2765. (https:// doi.org/10.1210/jc.2018-02399)

49 Eliakim A, Barzilai M, Wolach B \& Nemet D. Should we treat elevated thyroid stimulating hormone levels in obese children and adolescents? International Journal of Pediatric Obesity 20061 217-221. (https://doi.org/10.1080/17477160600805006)

50 Kumar S, Dayal D, Attri S, Gupta A \& Bhalla A. Levothyroxine supplementation for obesity-associated thyroid dysfunction in children: a prospective, randomized, case control study. Pediatric Endocrinology, Diabetes, and Metabolism 201925 107-113. (https:// doi.org/10.5114/pedm.2019.87709)

51 Krude $\mathrm{H} \&$ Blankenstein $\mathrm{O}$. Treating patients not numbers: the benefit and burden of lowering TSH newborn screening cut-offs. Archives of Disease in Childhood 201196 121-122. (https://doi. org/10.1136/adc.2009.174466)

52 Rabbiosi S, Vigone MC, Cortinovis F, Zamproni I, Fugazzola L, Persani L, Corbetta C, Chiumello G \& Weber G. Congenital hypothyroidism with eutopic thyroid gland: analysis of clinical and biochemical features at diagnosis and after re-evaluation. Journal of Clinical Endocrinology and Metabolism 201398 1395-1402. (https:// doi.org/10.1210/jc.2012-3174)

53 Lain S, Trumpff C, Grosse SD, Olivieri A \& Van Vliet G. Are lower TSH cutoffs in neonatal screening for congenital hypothyroidism warranted? European Journal of Endocrinology 2017177 D1-D12. (https://doi.org/10.1530/EJE-17-0107) 
54 Vigone MC, Capalbo D, Weber G \& Salerno M. Mild hypothyroidism in childhood: who, when, and how should be treated? Journal of the Endocrine Society 20182 1024-1039. (https://doi.org/10.1210/js.201700471)

55 Vigone MC, Di Frenna M, Guizzardi F, Gelmini G, de Filippis T, Mora S, Caiulo S, Sonnino M, Bonomi M, Persani L et al. Mild TSH resistance: clinical and hormonal features in childhood and adulthood. Clinical Endocrinology 201787 587-596. (https://doi. org/10.1111/cen.13387)

56 Calaciura F, Motta RM, Miscio G, Fichera G, Leonardi D, Carta A, Trischitta V, Tassi V, Sava L \& Vigneri R. Subclinical hypothyroidism in early childhood: a frequent outcome of transient neonatal hyperthyrotropinemia. Journal of Clinical Endocrinology and Metabolism 200287 3209-3214. (https://doi.org/10.1210/jcem.87.7.8662)

57 Mantovani G, Spada A \& Elli FM. Pseudohypoparathyroidism and Gs $\alpha$-cAMP-linked disorders: current view and open issues. Nature Reviews: Endocrinology 201612 347-356. (https://doi.org/10.1038/ nrendo.2016.52)

58 Szinnai G, Léger J, Bauer AJ, Pearce EN, Ramos HE, Canalli MH, Onigata K, Elisei R, Radetti G, Polak M et al. Clinical case seminar in pediatric thyroid disease. Endocrine Development 201426 214-244. (https://doi.org/10.1159/000363166)

59 Leonardi D, Polizzotti N, Carta A, Gelsomino R, Sava L, Vigneri R \& Calaciura F. Longitudinal study of thyroid function in children with mild hyperthyrotropinemia at neonatal screening for congenital hypothyroidism. Journal of Clinical Endocrinology and Metabolism 2008 93 2679-2685. (https://doi.org/10.1210/jc.2007-2612)

60 Mizuno H, Kanda K, Sugiyama Y, Imamine H, Ito T, Kato I, Togari H, Kamoda T \& Onigata K. Longitudinal evaluation of patients with a homozygous $\mathrm{R} 450 \mathrm{H}$ mutation of the TSH receptor gene. Hormone Research 200971 318-323. (https://doi.org/10.1159/000223415)

61 Tenenbaum-Rakover Y, Almashanu S, Hess O, Admoni O, HagDahood Mahameed A, Schwartz N, Allon-Shalev S, Bercovich D $\&$ Refetoff S. Long-term outcome of loss-of-function mutations in thyrotropin receptor gene. Thyroid 201525 292-299. (https://doi. org/10.1089/thy.2014.0311)

62 Strolin Benedetti M, Whomsley R, Baltes E \& Tonner F. Alteration of thyroid hormone homeostasis by antiepileptic drugs in humans: involvement of glucuronosyltransferase induction. European Journal of Clinical Phamacology 201561 863-872. (https://doi.org/10.1007/ s00228-005-0056-0)

63 Rosene ML, Wittmann G, Arrojo e Drigo R, Singru PS, Lechan RM \& Bianco AC. Inihibition of type 2 iodothyronine diodinase underlies the elevated plasma TSH associated with amiodarone treatment. Endocrinology 2010151 5961-5970. (https://doi.org/10.1210/ en.2010-0553)

64 Viganò A, Riboni S, Bianchi R, Cafarelli L, Vago T, Manzoni P \& Di Natale B. Thyroid dysfunction in antiretroviral treated children. Pediatric Infectious Disease Journal 200423 235-239. (https://doi. org/10.1097/01.inf.0000114903.05472.e4)

65 Verrotti A, Scardapane A, Manco R. \& Chiarelli F. Antiepileptic drugs and thyroid function. Journal of Pediatric Endocrinology and Metabolism 200821 401-408. (https://doi.org/10.1515/jpem.2008.21.5.401)

66 Chemaitilly W \& Cohen LE. Diagnosis of endocrine disease: endocrine late-effects of childhood cancer and its treatments. European Journal of Endocrinology 2017176 R183-R203. (https://doi. org/10.1530/EJE-17-0054)

67 Zimmermann MB \& Boelaert K. Iodine deficiency and thyroid disorders. Lancet: Diabetes and Endocrinology 20153 286-295. (https:// doi.org/10.1016/S2213-8587(14)70225-6)

68 Kang MJ, Hwang IT \& Chung HR. Excessive iodine intake and subclinical hypothyroidism in children and adolescents aged 6-19 years: results of the sixth Korean national health and nutrition examination survey, 2013-2015. Thyroid 201828 773-779. (https:// doi.org/10.1089/thy.2017.0507)
69 Wasniewska M, Salerno M, Cassio A, Corrias A, Aversa T, Zirilli G, Capalbo D, Bal M, Mussa A \& De Luca F. Prospective evaluation of the natural course of idiopathic subclinical hypothyroidism in childhood and adolescence. European Journal of Endocrinology 2009 160 417-421. (https://doi.org/10.1530/EJE-08-0625)

70 Morris CJ, Aeschbach D \& Scheer FA. Circadian system, sleep and endocrinology. Molecular and Cellular Endocrinology 2012349 91-104. (https://doi.org/10.1016/j.mce.2011.09.003)

71 Benvenga S, Di Bari F, Granese R \& Antonelli A. Serum thyrotropin and phase of the menstrual cycle. Frontiers in Endocrinology $2017 \mathbf{8}$ 250. (https://doi.org/10.3389/fendo.2017.00250)

72 Favresse J, Burlacu MC, Maiter D \& Gruson D. Interferences with thyroid function immunoassays: clinical implications and detection algorithm. Endocrine Reviews 201839 830-850. (https://doi. org/10.1210/er.2018-00119)

73 Hattori N, Ishihara T, Matsuoka N, Saito T \& Shimatsu A. Antithyrotropin autoantibodies in patients with macro-thyrotropin and long-term changes in macro-thyrotropin and serum thyrotropin levels. Thyroid 201727 138-146. (https://doi.org/10.1089/ thy.2016.0442)

74 Cerbone M, Bravaccio C, Capalbo D, Polizzi M, Wasniewska M, Cioffi D, Improda N, Valenzise M, Bruzzese D, De Luca F et al. Linear growth and intellectual outcome in children with longterm idiopathic subclinical hypothyroidism. European Journal of Endocrinology 2011164 591-597. (https://doi.org/10.1530/EJE-100979)

75 Wasniewska M, Corrias A, Aversa T, Valenzise M, Mussa A, De Martino L, Lombardo F, De Luca F \& Salerno M. Comparative evaluation of therapy with L-thyroxine versus no treatment in children with idiopathic and mild subclinical hypothyroidism. Hormone Research in Paediatrics 201277 376-381. (https://doi. org/10.1159/000339156)

76 Cerbone M, Capalbo D, Wasniewska M, Alfano S, Mattace Raso G, Oliviero U, Cittadini A, De Luca F \& Salerno M. Effects of L-thyroxine treatment on early markers of atherosclerotic disease in children with subclinical hypothyroidism. European Journal of Endocrinology 2016175 11-19. (https://doi.org/10.1530/EJE-15-0833)

77 Chase HP, Garg SK, Cockerham RS, Wilcox WD \& Walravens PA Thyroid hormone replacement and growth of children with subclinical hypothyroidism and diabetes. Diabetic Medicine 19907 299-303. (https://doi.org/10.1111/j.1464-5491.1990.tb01393.x)

78 Saggese G, Bertelloni S, Baroncelli GI, Costa S \& Ceccarelli C. Bone mineral density in adolescent females treated with Lthyroxine: a longitudinal study. European Journal of Pediatrics 1996155 452-457. (https://doi.org/10.1007/BF01955180)

79 Di Mase R, Cerbone M, Improda N, Esposito A, Capalbo D Mainolfi C, Santamaria F, Pignata C \& Salerno M. Bone health in children with longterm idiopathic subclinical hypothyroidism. Italian Journal of Pediatrics 201238 56. (https://doi.org/10.1186/18247288-38-56)

80 Horn S \& Heuer H. Thyroid hormone action during brain development: more questions than answers. Molecular and Cellular Endocrinology 2010315 19-26. (https://doi.org/10.1016/j. mce.2009.09.008)

81 Lain SJ, Bentley JP, Wiley V, Roberts CL, Jack M, Wilcken B \& Nassar N. Association between borderline neonatal thyroidstimulating hormone concentrations and educational and developmental outcome: a population-based record-linkage study. Lancet: Diabetes and Endocrinology 20164 756-765. (https://doi. org/10.1016/S2213-8587(16)30122-X)

82 Trumpff C, de Schepper J, Vanderfauillie J, Vercruysse N, Van Oyen H, Moreno-Reyes R, Tafforeau J, Vanderpas J \& Vandevijvere S. Thyroid-stimulating hormone (TSH) concentration at birth in Belgian neonates and cognitive development at preschool age. Nutrients 20157 9018-9032. (https://doi.org/10.3390/nu7115450) 
83 Trumpff C, de Schepper J, Vanderfauillie J, Vercruysse N, Van Oyen H, Moreno-Reyes R, Tafforeau J \& Vandevijvere S. Neonatal thyroid-stimulating hormone concentration and psychomotor development at preschool age. Archives of Disease in Childhood 2016 101 1100-1106. (https://doi.org/10.1136/archdischild-2015-310006)

84 Pérez-Lobato R, Ramos R, Arrebola JP, Calvente I, Ocón-Hernández O, Dávila-Arias C, Pérez-García M, Olea N \& Fernández MF. Thyroid status and its association with cognitive functioning in healthy boys at 10 years of age. European Journal of Endocrinology 2015172 129-139. (https://doi.org/10.1530/EJE-14-0093)

85 Ergür AT, Taner Y, Ata E, Melek E, Bakar EE \& Sancak T. Neurocognitive functions in children and adolescents with subclinical hypothyroidism. Journal of Clinical Research in Pediatric Endocrinology 20124 21-24. (https://doi.org/10.4274/Jcrpe.497)

86 Aijaz NJ, Flaherty EM, Preston T, Bracken SS, Lane AH \& Wilson TA. Neurocognitive function in children with compensated hypothyroidism: lack of short term effects on or off thyroxin. BMC Endocrine Disorders 20066 2. (https://doi.org/10.1186/1472-6823-6-2)

87 Kocaaslan Atli S, Olgaç Dündar N, Bayazit O, Evirgen Esin N, Erdoğan U, Çatli G, Kahya MC \& Dündar BN. Auditory event-related potentials demonstrate early cognitive impairment in children with subclinical hypothyroidism. Journal of Pediatric Endocrinology and Metabolism 201932 689-697. (https://doi.org/10.1515/jpem-20180463)

88 Sangün Ö, Demirci S, Dündar N, Pirgon Ö, Koca T, Doğan M \& Dündar B. The effects of six-month L-thyroxine treatment on cognitive functions and event-related brain potentials in children with subclinical hypothyroidism. Journal of Clinical Research in Pediatric Endocrinology 20157 102-108. (https://doi.org/10.4274/ jcrpe.1684)

89 Capalbo D, Alfano S, Polizzi M, Di Mase R, Improda N, Esposito A, Bravaccio C \& Salerno M. Cognitive function in children with idiopathic subclinical hypothyroidism: effects of 2 years of levothyroxine therapy. Journal of Clinical Endocrinology and Metabolism 2020105 dgaa046. (https://doi.org/10.1210/clinem/ dgaa046)

90 Cerbone M, Capalbo D, Wasniewska M, Mattace Raso G, Alfano S, Meli R, De Luca F \& Salerno M. Cardiovascular risk factors in children with long-standing untreated idiopathic subclinical hypothyroidism. Journal of Clinical Endocrinology and Metabolism 2014 99 2697-2703. (https://doi.org/10.1210/jc.2014-1761)

91 Paoli-Valeri M, Guzmán M, Jiménez-López V, Arias-Ferreira A, Briceño-Fernández M \& Arata-Bellabarba G. Atherogenic lipid profile in children with subclinical hypothyroidism. Anales de Pediatria 2005 62 128-134. (https://doi.org/10.1157/13071309)

92 Marwaha RK, Tandon N, Garg MK, Kanwar R, Sastry A, Narang A, Arora S \& Bhadra K. Dyslipidemia in subclinical hypothyroidism in an Indian population. Clinical Biochemistry 201144 1214-1217. (https://doi.org/10.1016/j.clinbiochem.2011.07.003)

93 Jin HY. Prevalence of subclinical hypothyroidism in obese children or adolescents and association between thyroid hormone and the components of metabolic syndrome. Journal of Paediatrics and Child Health 201854 975-980. (https://doi.org/10.1111/jpc.13926)

94 Dahl AR, Iqbal AM, Lteif AN, Pittock ST, Tebben PJ \& Kumar S. Mild subclinical hypothyroidism is associated with paediatric dyslipidaemia. Clinical Endocrinology 201889 330-335. (https://doi. org/10.1111/cen.13752)

95 Nader NS, Bahn RS, Johnson MD, Weaver AL, Singh R \& Kumar S. Relationships between thyroid function and lipid status or insulin resistance in a pediatric population. Thyroid 201020 1333-1339. (https://doi.org/10.1089/thy.2010.0180)

96 Le TN, Celi FS \& Wickham 3rd EP. Thyrotropin levels are associated with cardiometabolic risk factors in euthyroid adolescents. Thyroid 201626 1441-1449. (https://doi.org/10.1089/thy.2016.0055)

97 Zhang J, Jiang R, Li L, Li P, Li X, Wang Z, Li L \& Teng W. Serum thyrotropin is positively correlated with the metabolic syndrome components of obesity and dyslipidemia in Chinese adolescents. International Journal of Endocrinology 20142014 289503. (https://doi. org/10.1155/2014/289503)

98 Witte T, Ittermann T, Thamm M, Riblet NB \& Völzke H. Association between serum thyroidstimulating hormone levels and serum lipids in children and adolescents: a population-based study of German youth. Journal of Clinical Endocrinology and Metabolism 2015100 2090-2097. (https://doi.org/10.1210/jc.2014-4466)

99 Çatlı G, Anık A, Ünver Tuhan H, Böber E \& Abacı A. The effect of L-thyroxine treatment on hypothyroid symptom scores and lipid profile in children with subclinical hypothyroidism. Journal of Clinical Research in Pediatric Endocrinology 20146 238-244. (https:// doi.org/10.4274/Jcrpe.1594)

100 Li X, Wang Y, Guan Q, Zhao J \& Gao L. The lipid-lowering effect of levothyroxine in patients with subclinical hypothyroidism: a systematic review and meta-analysis of randomized controlled trials. Clinical Endocrinology 201787 1-9. (https://doi.org/10.1111/ cen.13338)

101 Lee MK, Kim YM, Sohn SY, Lee JH, Won YJ \& Kim SH. Evaluation of the relationship of subclinical hypothyroidism with metabolic syndrome and its components in adolescents: a population-based study. Endocrine 201965 608-615. (https://doi.org/10.1007/s12020019-01942-9)

102 Ittermann T, Thamm M, Wallaschofski H, Rettig R \& Völzke H. Serum thyroid-stimulating hormone levels are associated with blood pressure in children and adolescents. Journal of Clinical Endocrinology and Metabolism 201297 828-834. (https://doi.org/10.1210/jc.20112768)

103 Chen H, Xi Q, Zhang H, Song B, Liu X, Mao X, Li J, Shen H, Tang W, Zhang J et al. Investigation of thyroid function and blood pressure in school-aged subjects without overt thyroid disease. Endocrine 2012 41 122-129. (https://doi.org/10.1007/s12020-011-9517-7)

104 Çatli G, Kir M, Anik A, Yilmaz N, Böber E \& Abaci A. The effect of L-thyroxine treatment on left ventricular functions in children with subclinical hypothyroidism. Archives of Disease in Childhood 2015 100 130-137. (https://doi.org/10.1136/archdischild-2014-306381)

105 Arslan D, Buyukinan M, Uysal C \& Deniz CD. Evaluation of cardiovascular risk by growth-differentiation factor- 15 and tissue Doppler imaging in children with subclinical hypothyroidism. Endocrine 201965 601-607. (https://doi.org/10.1007/s12020-01901933-w)

106 Ergin Z, Savaş-Erdeve Ş, Kurnaz E, Çetinkaya S \& Aycan Z. Follow-up in children with non-obese and non-autoimmune subclinical hypothyroidism. Journal of Pediatric Endocrinology and Metabolism 201831 1133-1138. (https://doi.org/10.1515/jpem-2018-0095)

107 Fonseca V, Guba SC \& Fink LM. Hyperhomocysteinemia and the endocrine system: implications for atherosclerosis and thrombosis. Endocrine Reviews 199920 738-759. (https://doi.org/10.1210/ edrv.20.5.0381)

108 Atabek ME, Pirgon O \& Erkul I. Plasma homocysteine concentrations in adolescents with subclinical hypothyroidism. Journal of Pediatric Endocrinology and Metabolism 200316 1245-1248. (https://doi. org/10.1515/jpem.2003.16.9.1245)

109 Rumińska M, Witkowska-Sędek E, Majcher A, Brzewski M, Krawczyk M \& Pyrżak B. Serum TSH level in obese children and its correlations with atherogenic lipid indicators and carotid intima media thickness. Journal of Ultrasonography 201818 296-301. (https://doi.org/10.15557/JoU.2018.0043)

110 Svensson J, Ericsson UB, Nilsson P, Olsson C, Jonsson B, Lindberg B $\&$ Ivarsson SA. Levothyroxine treatment reduces thyroid size in children and adolescents with chronic autoimmune thyroiditis. Journal of Clinical Endocrinology and Metabolism 200691 1729-1734. (https://doi.org/10.1210/jc.2005-2400)

111 Scarpa V, Kousta E, Tertipi A, Vakaki M, Fotinou A, Petrou V, Hadjiathanasiou C \& Papathanasiou A. Treatment with thyroxine reduces thyroid volume in euthyroid children and adolescents with 
chronic autoimmune thyroiditis. Hormone Research in Paediatrics 2010 73 61-67. (https://doi.org/10.1159/000271917)

112 Francis GL, Waguespack SG, Bauer AJ, Angelos P, Benvenga S, Cerutti JM, Dinauer CA, Hamilton J, Hay ID, Luster M et al. Management guidelines for children with thyroid nodules and differentiated thyroid cancer. Thyroid 201525 716-759. (https://doi. org/10.1089/thy.2014.0460)

113 Iglesias ML, Schmidt A, Ghuzlan AA, Lacroix L, Vathaire F, Chevillard S \& Schlumberger M. Radiation exposure and thyroid cancer: a review. Archives of Endocrinology and Metabolism 201761 180-187. (https://doi.org/10.1590/2359-3997000000257)

114 Léger J, Olivieri A, Donaldson M, Torresani T, Krude H, van Vliet G, Polak M, Butler G \& ESPE-PES-SLEP-JSPE-APEG-APPESISPAE. Congenital Hypothyroidism Consensus Conference Group. European Society for Paediatric Endocrinology consensus guidelines on screening, diagnosis, and management of congenital hypothyroidism. Journal of Clinical Endocrinology and Metabolism 2014 99 363-384. (https://doi.org/10.1210/jc.2013-1891)

Received 18 January 2020

Revised version received 28 March 2020

Accepted 6 May 2020 